\title{
Making the Case: Adding Case Studies to an Environmental Engineering Laboratory to Increase Student Engagement, Learning, and Data Analysis
}

\section{Dr. Stephanie Luster-Teasley, North Carolina A\&T State University}

Dr. Stephanie Luster-Teasley is an Associate Professor with a joint appointment in the Departments of Civil, Architectural, and Environmental Engineering, and Chemical, Biological, and Bioengineering. Over the last ten years, Dr. Luster-Teasley has demonstrated excellence in teaching by using a variety of research-based, student-centered, pedagogical methods to increase diversity in STEM. Her teaching and engineering education work has resulted in her receiving the 2013 UNC Board of Governors Teaching Excellence Award, which is the highest teaching award conferred by the UNC system for faculty. In 2014, she was also the recipient of the ASEE Dupont Minorities in Engineering Award.

\section{Dr. Sirena C. Hargrove-Leak, Elon University}

Sirena Hargrove-Leak is an Associate Professor in the Dual-Degree Engineering Program at Elon University in Elon, NC. The mission and commitment of Elon University have led her to explore the scholarship of teaching and learning in engineering and service-learning as a means of engineering outreach. Hargrove-Leak is an active member of the American Society for Engineering Education. With all of her formal education in chemical engineering, she also has interests in heterogeneous catalysis for fine chemical and pharmaceutical applications and membrane separations.

\section{Dr. Willietta Gibson}

Dr. Willietta Gibson, a native of Durham, North Carolina, is an Assistant Professor of Biology at Bennett College. She received her B.S degree in Molecular Biology from Winston-Salem State University and Ph.D. in Biomedical Science from the Medical University of South Carolina. She also completed a postdoctoral fellowship at the Biomanufacturing Research Institute and Technology Enterprise (BRITE) at North Carolina Central University (NCCU) where she examined the sensitivity of inflammatory breast cancer cells to commercially available inhibitors of the sonic hedgehog signal transduction pathway. Dr. Gibson's research interests include breast cancer health disparities amongst African-American women, natural products as chemopreventive agents in breast cancer and undergraduate STEM education. Dr. Gibson has taught Principles of Biology I and II, Comparative Vertebrate Anatomy, Human Biology, Zoology and Biotechnology. She has a deep passion for teaching, helping others to learn, mentoring and increasing the number of underrepresented minorities entering into STEM graduate programs. 


\section{Making the Case: Adding case studies to an Environmental Engineering Laboratory to increase student engagement, learning, and data analysis}

Case studies are innovative ways to increase student engagement in courses. Used extensively in medical and law schools, case studies introduce real-world examples that can help students readily see how theory applies to actual events, situations, and the end results. This educational study began in 2010 to investigate the use of case studies in an environmental engineering laboratory course. Four environmental engineering case studies combined with laboratory activities were developed for a junior level environmental engineering course. The cases were added to the laboratory course as a way to update laboratory content with contemporary themes, real world examples, and new topics such as sustainability. The rationale for implementing the cases within a traditional laboratory was to determine if the cases impacted student engagement; helped students to see the link between laboratory exercises and real world applications; increased student's critical thinking levels above the lower levels of Bloom's Taxonomy of knowledge and comprehension for their experimental data; and improved the quality of student laboratory reports. The new cases developed addressed: 1) E-waste to teach environmental ethics and statistical analysis of data, 2) the 2014 Duke Coal Ash Spill in Danville, VA to teach physical and chemical water quality and treatment; 3) a Confined Animal Feeding Operations water contamination case to teach biological impacts to water quality and microbial quantification; and 4) Green buildings to teach sustainable engineering concepts. For this study, two laboratory course sections were studied. A control group of students experienced a traditional lab and was compared to an intervention group where cases were used with each laboratory experiment. Quantitative and qualitative assessments included a survey to assess student impression of the use of cases in a laboratory course and evaluation of student lab reports for quality and content by two external reviewers. Student learning styles were also assessed using the Index of Learning Styles Survey (ILS) by Felder and Solomon. The ILS instrument can be used to assess student learning styles of active/reflective, sensing/intuitive, visual/verbal and sequential/global before instruction of the case study. The results confirm that the majority of the students were active, sensing, visual and sequential learners. These characteristics are ideal for the use of cases and hands-on interactive instruction. Overall, the students found the use of cases more engaging and the cases elevated their interest in laboratory discussions and course content. External evaluation of the student reports suggest that the use of cases did not significantly improve the quality of the student laboratory reports, however, student interpretation and analysis of data slightly improved. 


\section{Purpose of Study}

Laboratory courses are an integral part of many engineering curricula due to the opportunity to provide hands-on experiences for students to learn how to collect and analyze data. While laboratory experiences diverge from a formal classroom lecture to allow students to conduct experiments related to real-world disciplinary concepts, many engineering laboratories use a "cookbook" and procedural based structure. These traditional laboratories, however, have been proven to only address the lower levels of knowledge and comprehension of Blooms Taxonomy as opposed to reaching the higher levels of application, analysis, synthesis, and evaluation. ${ }^{1-3}$ Therefore, even though students are engaged in hands-on activities during lab instruction, educators can question several key areas for lab instruction effectiveness and their students' ability to reach the higher levels of Bloom's encompassing application, analysis, synthesis, and evaluation. Are students understanding and retaining the lab concepts? Are students expanding their critical thinking skills during the laboratory? Is the student motivation to learn the concept or just finish the lab as fast as possible? What is the student's ability to apply lab concepts to real-world applications?

Case studies are innovative ways to increase student engagement, motivation, application of critical thinking skills, and can help students integrate concepts learned in the course for problem-solving skill. ${ }^{4-8}$ Used extensively in medical and law schools, case studies introduce real-world examples that can help students readily see how theory applies to actual events, situations, and the end results. ${ }^{8-11}$ This educational study began in 2010 to investigate the use of case studies in an environmental engineering laboratory course. The rationale for implementing the cases within a traditional laboratory was to determine if the cases impacted student engagement; helped students to see the link between laboratory exercises and real world applications; increased student's critical thinking levels above the lower levels of Bloom's Taxonomy of knowledge and comprehension for their overall understanding of lab concepts; and improved the quality of student laboratory reports. For this educational study, we hypothesized, the use of cases in conjunction with teaching laboratory concepts, could improve student understanding and critical thinking to higher order Bloom's Taxonomy by providing a real-world examples related to the laboratory concepts and the application of the laboratory skills.

\section{Methodology}

Four original environmental engineering case studies were combined with laboratory activities in a junior level environmental engineering course taught at North Carolina A\&T State University (NCA\&T). This environmental engineering laboratory course is required for all civil engineering majors and is part of a series of three mandatory environmental engineering courses within our curriculum. The junior level, environmental engineering laboratory is taught as a corequisite ( 1 credit hour meeting 2 hours per week) for our Introduction to Environmental Engineering lecture course ( 3 credit hours). The laboratory is offered using two sections with an average of 16 students enrolled per section. The laboratory component is designed to provide the students with the opportunity to learn how to collect and analyze environmental samples. In particular, this laboratory focuses on water analyses. Demographically, the students enrolled in the course were $68 \%$ male and $31 \%$ female. Our university is a minority serving institution, therefore, by race or ethnicity, the class was $80 \%$ African-American, $7 \%$ Caucasian, and $13 \%$ representation by students from India or the Middle East. 
We selected cases that would update the content in an environmental engineering laboratory course with contemporary themes, real world examples, and new sustainability themes. The new cases developed addressed: 1) E-waste to teach environmental ethics and statistical analysis of data, 2) the 2014 Duke Coal Ash Spill in Danville, VA to teach physical and chemical water quality and treatment; 3) a Confined Animal Feeding Operations water contamination case to teach biological impacts to water quality and microbial quantification; and 4) Green buildings to teach sustainable engineering concepts. For this study, a control group of students experienced a traditional lab and a second intervention group of students were taught the laboratory course using cases associated with each laboratory experiment.

This study was divided into three parts. Part one was the development of the cases. Part two sought to understand the learning style profiles for students in the course to determine if students strongly favored one learning style over another; hence, providing a class profile for the best pedagogy to use to teach a course. The third part consisted of implementing the cases in one of the two lab courses and determining student impression of the use of the cases with the lab.

\section{Part 1. Development of the Cases}

For the case development, we wanted to create cases that would address the same content as the traditional laboratories but promote more discussion and critical thinking for the students as they learned the laboratory skills. Four original case studies were developed using the Herreid (1997) definition of the components for a good case study used in the sciences. ${ }^{12,13}$ The National Center for Case Study Teaching in Science (NCCSTS) model recommends several key factors for developing a good case. ${ }^{12}$ These are: 1) the case tells a story; 2) it focuses on an interesting-arousing issue; 3 ) the case is set within the past five years and can be real or fictional as long as it is factual; 4) it creates empathy with the central characters; 5) the case must have pedagogic utility; and 5) the case is short. Cases submitted to NCCSTS are peer reviewed and published in a database. Table 1 lists the four cases and tour developed for the educational study to be used in the laboratory course compared to the traditional lab.

\section{Part 2. Learning Styles}

Student learning styles were assessed using the Index of Learning Styles Survey (ILS). The ILS is a free assessment tool developed by Richard Felder and Barbara Soloman [http://www.ncsu.edu/felder-public/ILSpage.html]. This instrument is a 40 question assessment which categorizes the student's learning into several groups and has been validated by a number of previous studies. ${ }^{14,15}$ These learning styles are: Active Learners versus Reflective learners, Sensing Learners versus Intuitive Learners, Visual Learners versus Verbal Learners, and Sequential Learners versus Global Learners. ${ }^{16}$ Participants are scored with odd numbered values between $1-11$ on their propensity to prefer one from of learning over another based on the Active vs Reflective, Sensing vs Intuitive, Visual vs Verbal, or Sequential vs Global categories. For the scale a ranking of 1 or 3 indicates the student has a mild preference for the learning style. A score between 5 or 7 is a moderate preference for the learning style, and a score between 9 or 11 indicates a strong preference for the learning style. 


\section{Table 1. Overview of Case Study topics and Laboratory Learning Objective}

\begin{tabular}{|c|c|c|}
\hline $\begin{array}{l}\text { Case } \\
\text { Study }\end{array}$ & Learning and Skills Goals & $\begin{array}{c}\text { Traditional Lab } \\
\text { Replaced }\end{array}$ \\
\hline E-waste & $\begin{array}{l}\text { Type of Case: Fictional character experiencing a real world event or } \\
\text { environmental concern. } \\
\text { Case: Students assume the role of engineers and scientist sent to } \\
\text { investigate illnesses in workers exposed to hazardous e-waste. Using a } \\
\text { method to randomly generate data for the occurrence of illnesses in } \\
\text { workers who were protective equipment versus workers who do not wear } \\
\text { protective equipment, the students perform statistical analysis on the data } \\
\text { and must predict the probability of illnesses occurring in the workers. } \\
\text { Learning Objective: Students will learn about hazardous chemicals } \\
\text { contained in electronic waste. They will learn about disposal practices in } \\
\text { the US versus third world countries and discuss environmental ethics and } \\
\text { justice. They will learn about the types of hazardous waste present in e- } \\
\text { waste and how people in China and Ghana live where unsafe and } \\
\text { illegal recycling practices occur. Skills: Practice statistical analysis } \\
\text { calculations and must complete calculations for mean, median, mode, } \\
\text { standard deviation, 95\% confidence interval using a statistical analysis } \\
\text { software package; understanding chemical hazardous waste, public } \\
\text { health, and risk assessment; environmental ethics and justice. }\end{array}$ & $\begin{array}{l}\text { Lab 1\&2: Statistical } \\
\text { Analysis of data, } \\
\text { Accuracy and } \\
\text { Precision of data } \\
\text { Learning Objectives: } \\
\text { This is an introductory } \\
\text { lab conducted the first } \\
\text { week of classes where } \\
\text { the students compare } \\
\text { the accuracy of the } \\
\text { different glassware } \\
\text { and their precision. } \\
\text { Students practice } \\
\text { statistical analysis } \\
\text { calculations and must } \\
\text { complete calculations } \\
\text { for mean, median, } \\
\text { mode, standard } \\
\text { deviation, 95\% } \\
\text { confidence interval } \\
\text { using a statistical } \\
\text { analysis software } \\
\text { package. }\end{array}$ \\
\hline $\begin{array}{l}\text { Duke } \\
\text { Energy } \\
\text { Coal Ash } \\
\text { Spill }\end{array}$ & $\begin{array}{l}\text { Type of Case: Real World Case Studies (actual events) } \\
\text { Case: This case study discussed the accidental release of coal ash from a } \\
\text { regional energy company into a local river used for drinking water in } \\
\text { Virginia and North Carolina in February } 2014 \text {. } \\
\text { Learning Objective: Students will learn about the } 2014 \text { Duke Energy } \\
\text { Coal Ash Spill in Danville, Virginia and parts of North Carolina. The } \\
\text { release was due to improper disposal and maintenance practices at the } \\
\text { energy plant. The case is used to teach environmental policies, } \\
\text { environmental ethics and justice, and physical and chemical water } \\
\text { quality. Skills: Distinguish dissolved solids, suspended solids, filterable } \\
\text { solids, and settable solids; environmental policy, regulations, EPA } \\
\text { reporting requirements, and public impact } \\
\text { Part 1: For the lab, students learn how to measure Total Suspended } \\
\text { Solids, total dissolved solids, fixed suspended solids, settleable solids } \\
\text { using simulated water samples. } \\
\text { Part 2: Students attempt to build a water filtration system to improve } \\
\text { color, odor, and turbidity in the simulated water samples. }\end{array}$ & $\begin{array}{l}\text { Lab 3: } \\
\text { TDS/TSS/TFS/SS } \\
\text { Learning Objective: } \\
\text { Measurement of total } \\
\text { suspended solids, total } \\
\text { dissolved solids, fixed } \\
\text { suspended solids, } \\
\text { settleable solids using } \\
\text { simulated water } \\
\text { samples. } \\
\text { Lab 4: Physical } \\
\text { Treatment } \\
\text { techniques for water } \\
\text { and water quality } \\
\text { parameters } \\
\text { Learning Objectives: } \\
\text { Students will design a } \\
\text { water filtration system } \\
\text { and must improve pH, } \\
\text { turbidity, color and } \\
\text { water for a simulated } \\
\text { water sample }\end{array}$ \\
\hline
\end{tabular}


Table 1. Continued

\begin{tabular}{|c|c|c|}
\hline $\begin{array}{l}\text { Case } \\
\text { Study }\end{array}$ & Learning and Skills Goals & $\begin{array}{c}\text { Traditional Lab } \\
\text { Replaced }\end{array}$ \\
\hline $\begin{array}{l}\text { Ms. Hines } \\
\text { and the } \\
{\text { Sick } 5^{\text {th }}}^{\text {Graders }}{ }^{1}\end{array}$ & $\begin{array}{l}\text { Type of Case: Real World Case Studies (actual events) } \\
\text { Case: This case presented concepts for confined animal feeding } \\
\text { operations and their impact to water quality using a town hall meeting } \\
\text { format and testimonies from characters impacted by agricultural waste } \\
\text { from the CAFOs. } \\
\text { Learning Objectives: Students will learn how to perform chemical } \\
\text { analyses of water samples. The assay kits used for the laboratory include } \\
\text { measuring for nitrate, phosphate, alkalinity, turbidity, hardness, } \\
\text { ammonia, and chemical oxygen demand. Skills: Environmental justice } \\
\text { and ethics, discerning fact and bias, nitrate and phosphate contamination } \\
\text { of soil and water, applying EPA regulations for fecal coliform } \\
\text { contamination in drinking water and recreational water, and quantitative } \\
\text { measurement of bacteria. } \\
\text { Type of Case: Fictional character experiencing a real world event or } \\
\text { environmental concern. } \\
\text { Case: Students read a fictional story about an elementary teacher and } \\
\text { students who participated in a field trip to a local park and beome ill. } \\
\text { While at the park, the story characters visted locations where they } \\
\text { potentially could have been exposed to bacteria contaminated water. For } \\
\text { the case, the laboraotry students were presented with maps depicting the } \\
\text { sites where the class visited and for the laboroatry exercise they must } \\
\text { collect water samples from the park, perform field measurements, and } \\
\text { bring smaples back to the laboratory to quantify bacteria levels in the } \\
\text { water samples. } \\
\text { field and perform field measurements such as pH, turbidity, and } \\
\text { temperature using portable equipment. In the laboratory, they learn how } \\
\text { to perform microbial analysis using Membrane Filtration and IDEXX. } \\
\text { Skills: Field sampling protocols, biological, chemical, and physical } \\
\text { analysis for water quality }\end{array}$ & $\begin{array}{l}\text { Lab 5: } \\
\text { Understanding } \\
\text { Water quality and } \\
\text { Chemical and } \\
\text { Physical properties } \\
\text { for water } \\
\text { Learning Objective: } \\
\text { Students learn how to } \\
\text { perform assays to } \\
\text { measure nitrate/nitrite, } \\
\text { phosphate, alkalinity, } \\
\text { turbidity, hardness, } \\
\text { ammonia, COD. } \\
\text { Lab 6\&7: } \\
\text { Quantification of } \\
\text { bacteria }\end{array}$ \\
\hline $\begin{array}{l}\text { Green } \\
\text { Building } \\
\text { Practices }\end{array}$ & $\begin{array}{l}\text { Type of Case: Tour } \\
\text { Case: This is a tour of an eco-friendly, LEED Platinum hotel located in } \\
\text { Greensboro, NC. The Proximity Hotel was built to use } 40 \% \text { less energy } \\
\text { and } 30 \% \text { less water than traditional hotels. During the tour, students see } \\
\text { the sustainable design and engineering practices at the hotel. Some of } \\
\text { these features include solar panels, xeriscaping, recycled materials for } \\
\text { building and decorating the hotel, use of local suppliers to reduce the } \\
\text { carbon footprint, a geothermic kitchen, and water recycling. }\end{array}$ & $\begin{array}{l}\text { Lab 8: Green } \\
\text { Building Practices and } \\
\text { Sustainability } \\
\text { Learning Objective: } \\
\text { Students learn how } \\
\text { sustainable concepts } \\
\text { and the engineering }\end{array}$ \\
\hline
\end{tabular}


Table 1. Continued

\begin{tabular}{|c|c|c|}
\hline & $\begin{array}{l}\text { Learning Objective: Students will learn about alternative energy. They } \\
\text { will conduct an experiment using a solar panel to determine maximum } \\
\text { solar energy collected based on location and solar panel angle or conduct } \\
\text { an experiment on the cooling effect of a green roof. Students will } \\
\text { perform statistical analysis of the data collected. Skills: Explore } \\
\text { sustainable practices and green technologies such as solar panels, } \\
\text { xeriscaping, water recycling, use of local and recycle materials, and } \\
\text { sustainable practices that could be incorporated into a building. }\end{array}$ & $\begin{array}{l}\text { design of a Green } \\
\text { Building. }\end{array}$ \\
\hline
\end{tabular}

1. This case was renamed "No longer fond of the local pond" and published in 2015 by NCCSTS ${ }^{17}$.

2. Farmville Future was peer-reviewed and published by NCCSTS in $2013^{18}$.

\section{Part 3. Implementation in class}

Two environmental engineering laboratory sections were offered on Fridays for two hours in duration. Sixteen students were enrolled in each section and the students were divided into lab teams of four. One section was offered in the morning and the other in the afternoon. The control and the intervention laboratory sections were randomly chosen and students were not told about the differences in the instructional methods between the two laboratory course sections. The same professor taught both the control and intervention sections to maintain consistency in the course instructor. This instructor has taught the class using cases for 6 years. In 2015, this educational research was funded as part of a multi-university NSF IUSE grant. The protocol for the educational research was refined to conduct the research using a control group that received only a traditional laboratory experience and an intervention group that received case-based laboratories. The use of the control and intervention groups was used in the course in 2015 and is currently being used in the 2016 course.

\section{Control Laboratory Group}

The control group was provided the lab procedure the week before the laboratory experiment would be conducted. Students were required to come to class with their lab notebook prepared with the information needed for the laboratory procedure and tables for data collection related to the lab. They would then conduct the laboratory activities as a group and write a group lab report which was due 1-2 weeks after completing the laboratory exercise.

\section{Intervention Laboratory Group}

For the intervention group, students were assigned the case story and laboratory procedure to read as part of their pre-laboratory preparation. They were required to answer questions related to the case and laboratory procedures. This method is similar to a "flipped" method where students must read and prepare prior class with the goal of students learning the background content, or case information related to the lab, prior to the laboratory exercise. During the laboratory class, students were asked to complete the pre-lab questions as a graded assignment. For the first 5-10 minutes of class, we discussed the cases, pre-lab questions, and the steps for the laboratory. Following the laboratory exercises, a closing class discussion occurred which linked the experimental steps to what an engineer would do for the real case. This portion was facilitated by the professor but was mostly student driven for how the techniques learned during lab would be integral to the case study and real world applications. Student teams were required to complete a laboratory report due $1-2$ week after completing the laboratory exercise where they were asked to analyze their data and research the case study to provide additional 
background content for the laboratory report. For the research and reporting phase, students could research the topic online, find videos, or articles to gain additional insight in the topic. This model facilitates students independently learning the material outside of class and doing the active learning during the classroom time.

\section{Assessment of Use of case study method}

This educational study is covered by the NCA\&T IRB protocol \#11-0001. As per the IRB protocol, students enrolled in the course were required to participate in the laboratory activities as part of their environmental engineering laboratory curriculum; however, their participation in the surveys and interviews is voluntary. A mixed methods approach was used to assess the outcomes in this study. Quantitative and qualitative assessments conducted in 2014 and 2015 included a survey to assess student impression of the use of cases in a laboratory course, focus groups with students, and evaluation of student lab reports for quality and content by two external reviewers.

At the end of the course, students were provided with a survey to assess their impression of the case study method. The case study survey administered to the students was modified from the survey instrument used by Yadav et al (2010) to evaluate student impression in a Mechanical Engineering course which used cases. ${ }^{19}$ This survey consisted of 22 questions related to use of cases and student impression of the case study method. This assessment used a 5-point Likert scale ranging from Strongly Disagree (1) to Strongly Agree (5). The questions were designed to assess student perception of learning gains, synthesis and analysis, classroom environment and instruction, and negative impressions. The questions were also presented to the students in a mixed order to reduce biases in student responses based on the general themes.

The external evaluation of the study was an unbiased review of the student laboratory reports to compare the quality of the student's work between the control and intervention groups and to assess the levels of Bloom's Taxonomy reached between the groups. For the external evaluation, two faculty members who also use case studies in their courses were provided with anonymous student reports. They were not informed as to which reports were written by students in the control or intervention groups. Using a Likert scale and a grading rubric ranging from 0 to 3 where zero represented poor/no evidence and 3 represented exemplarily. The evaluators rated the quality of the report, data analysis, presentation of data using tables and figures, and critical thinking and analysis of the results.

\section{Results}

The ILS assessment was performed to quantitatively measure the learning preferences of the students in the course and ascertain if there would be a particular teaching technique that would benefit the students in the course. For example, Felder et al (1988) argues that most engineering teaching methods are reflective, intuitive, verbal, and sequential. Therefore, to engage students in the laboratory course, we wanted to confirm the learning styles present in the classroom and use teaching techniques with the cases that would best engage the dominate learning styles represented in the class. Of course, teaching styles should benefit multiple learning styles. Therefore, the non-dominate learning styles would continue to be addressed and incorporated into the teaching methods, however, a focus would be to deliver content using the 
style represented the most by the group. Additionally, we wanted to provide a connection between the theories, practice, and ultimately see if the intervention could improve the critical thinking and quality of the student reports beyond knowledge and comprehension reached by "cookbook" style labs.

The initial research hypothesis for engineering learners was that there would be strong preferences for learning styles that fit the traditional thoughts associated with engineering personalities where students are visual, sensing, and active learners. ${ }^{20}$ These characteristics are consistent with being logical, math-driven, and seeking sequential pathways for learning. Table 2 presents the percent of students with low, mid, and high preferences within each of the learning style categories. Participation in the ILS was voluntary. During Spring 2014 and Spring 2015, a total of 62 students participated in the laboratory course and 59 students completed the ILS survey. The ILS assessment score participants with odd numbered values between $1-11$ on their propensity to prefer one form of learning over another based on the Active vs Reflective, Sensing vs Intuitive, Visual vs Verbal, or Sequential vs Global categories. For the scale, a ranking of 1 - 3 indicates the student has a mild preference for the learning style. A score between 5 - 7 is a moderate preference for the learning style, and a score between 9 - 11 indicates a strong preference for the learning style.

Table 2. Student percentage representation of learning preferences at the low, moderate, and high preference ranges $(n=59)$.

\begin{tabular}{|lcccc|ccccc|}
\hline & $\begin{array}{c}\text { Mild } \\
\text { Pref }\end{array}$ & $\begin{array}{c}\text { Moderate } \\
\text { Pref }\end{array}$ & $\begin{array}{c}\text { High } \\
\text { Pref }\end{array}$ & Total & & $\begin{array}{c}\text { Mild } \\
\text { Pref } \\
\mathbf{5 - 7}\end{array}$ & $\begin{array}{c}\text { Moderate } \\
\text { Pref }\end{array}$ & $\begin{array}{c}\text { High } \\
\text { Pref } \\
\mathbf{9 - 1 1}\end{array}$ & Total \\
\hline Active & $35.6 \%$ & $27.1 \%$ & $1.7 \%$ & $64 \%$ & Reflective & $27.1 \%$ & $5.1 \%$ & $3.4 \%$ & $36 \%$ \\
Sensing & $47.5 \%$ & $27.1 \%$ & $13.6 \%$ & $88 \%$ & Intuitive & $6.8 \%$ & $5.1 \%$ & $0.0 \%$ & $12 \%$ \\
Visual & $25.4 \%$ & $28.8 \%$ & $40.7 \%$ & $95 \%$ & Verbal & $3.4 \%$ & $1.7 \%$ & $0.0 \%$ & $5 \%$ \\
Sequential & $49.2 \%$ & $27.1 \%$ & $0.0 \%$ & $76 \%$ & Global & $18.6 \%$ & $5.1 \%$ & $0.0 \%$ & $24 \%$ \\
\hline
\end{tabular}

Active learners represented $64 \%$ of the students and reflective learners represented $36 \%$. A statistical analysis of the mean $(\mu)$ learning style preference among the students suggests there is a statistical preference which favors active learning $(\mathrm{p}=0.015)$. Observing the mean within the active learners $(\mu=3.68)$ and the mean within the reflective learning group $(\mu=3.00)$ shows that students have a mild preference for their particular learning style and there is not a significant difference between in the means within the group when compared $(p=0.34)$. Active learners tend to understand and learn information best by doing something active such as discussing or applying the material. These learners benefit by actively participating in laboratory and hands-on activities. Reflective learners are learners who prefer to think about material before applying the material learned in a course. These learners can use the case studies to reflect over the problem or the framework story associated to the module activities. Therefore, both active and reflective styles can benefit for the cases.

Sensing students represented $88 \%$ of the student population while intuitive represented $12 \%$ of the students. A statistical analysis of the mean learning style preference suggests there is a statistical preference which favors sensing learning $(\mathrm{p} \leq 0.05)$. Observing the mean within the sensing learners $(\mu=4.50)$ and the mean within the intuitive learning group $(\mu=3.39)$ shows that 
students have a mild to moderate preference for their particular learning style and there is not a significant difference between the means within the group when compared $(p=0.16)$. Sensing Learners prefer to learn facts and solve problems by well-established methods. This finding is consistent with the problem solving, logical and math-driven nature of engineering students. Intuitive learners prefer to investigate possibilities and relationships. These learners are more comfortable with abstractions and mathematical formulations. Intuitive learners can use the case studies to investigate "what if" scenarios in their projects. The sequential preference by the students would suggest use of cases that present facts where students can use well-established methods such as laboratory procedures to solve a problem that could enhance learning. This is consistent with the model we chose to use for the cases combined with the laboratory exercises.

The majority of the students represented visual learners (95\%). The mean score for verbal learners was 6.8 and the mean for visual learners was 3.0. The average student representation is at a moderate to high level for verbal learning within the course and there is a significant difference between the means within the groups $(p \leq 0.05)$. Visual learners learn best through the use of pictures, images, and the opportunity to see visual representations of what they are learning. Therefore, long verbose written cases would not be as impactful as short case narratives combined with videos, pictures, and the opportunity for students to search for information on the internet related to the cases.

For the sequential versus global learning preferences, $76 \%$ of the students were sequential learners and 24\% were global. A statistical analysis of the mean learning style preference suggests there is a statistical preference which favors sequential learning $(\mathrm{p} \leq 0.05)$. Observing the mean within the sequential learners $(\mu=3.53)$ and the mean within the global learning group $(\mu=2.57)$ shows that students have a mild preference for their particular learning style and there is not a significant difference in the means within the group when compared $(p=0.17)$. Sequential learners tend to learn using linear steps in a logical order or pattern. Global learners learn by understanding the "big picture" and then linking concepts. Sequential learners have the structure of the laboratory procedure and logically can use the time before class with the "flipped" method see how the case relates to the laboratory experiment.

\section{Impression of cases}

Student responses during the focus group interviews and from an open-ended question asked on the end of semester survey were collected to obtain qualitative feedback. Responses ranged from "best lab class experience" to "the case studies were more work but interesting." The most common themes ranked from highest to lowest: 1) enjoyment of the cases due to the real world and "relatability", 2) the ability to apply learning outside of classroom, 3) interactive and interesting, 4) they felt they understood more/increased knowledge, 5) perspective about application of laboratory skills, 6) rationale for what we are learning, 7) interest/personal investment, and 8) ability to research topics (i.e. able to use internet for videos, websites about the topic, etc). The students suggested that the selection of cases needed to be appropriate for the course and the activity and cases are not necessary for all activities. They would like to see a mixture of teaching styles and not only cases taught within a course. A sub-set of students felt the use of the cases required more work due to the extra reading and the research performed for the cases. The university course evaluation completed by the students at the end of the semester 
resulted in students in the intervention laboratory class rating the course at 4.82/5.0 and for the control laboratory course the rating was $4.92 / 5.0$ scale.

The student impression survey demonstrated a positive perception of learning using the cases (Table 3). From the survey questions focusing on student learning, 98\% of the students that participated in the case intervention group, agreed or strongly agreed the use of the cases was relevant to learning about the course concepts. The majority of the student believed the cases allowed them to retain more and they took a more active role in the learning process with the cases. Under the Thinking, Synthesis, and Analysis survey question category, $72-80 \%$ of the student strongly agreed the case studies helped them analyze the basic elements of the course concepts, synthesize material, view an issue from multiple perspectives, and gain a deeper understanding. A small percentage (7.7\%) of students disagreed or strongly disagreed that the cases were thought provoking. Student indicated the classroom environment and instruction was positively impacted by the cases where they felt more engaged in the class, participated in discussions, and the cases added realism.

For the survey questions addressing negative impressions of the method, the students demonstrated mixed feelings. The student response about the cases being more entertaining than educational was divided where $45 \%$ perceived it as more entertaining than educational, $33 \%$ were neutral, and $22 \%$ felt it was more educational than entertaining. Students disagreed (62\%) with the survey question asking if the cases were frustrating. They also disagreed at a level of $74 \%$ that the use of the cases was inefficient or not necessary with the laboratory. The students' response to the use of the cases being more challenging can be perceived negatively if the goal is to increase rigor using the case with the laboratory or positively in that the addition of the cases does not increase student anxiety or the students feeling over burdened by the additional work involved in learning about the case. For the negative impression questions, the student responses show the majority of the students disagreed with the perception of the cases being frustrating, inefficient, or more time consuming.

Table 3. The Case Studies Impression Survey grouped based on the question theme and student responses

\begin{tabular}{|c|c|c|c|c|c|c|c|c|}
\hline \multicolumn{2}{|c|}{ Question Theme: Learning } & SA & A & $\mathbf{N}$ & D & SD & Avg & stdv \\
\hline Q1 & $\begin{array}{l}\text { I felt the use of case studies was relevant in learning } \\
\text { about the course concepts }\end{array}$ & 84.6 & 13.5 & 1.9 & 0.0 & 0.0 & 4.83 & 0.43 \\
\hline Q3 & $\begin{array}{l}\text { I felt that what we were learning in using the case } \\
\text { studies was applicable to my field of study }\end{array}$ & 82.7 & 15.4 & 1.9 & 0.0 & 0.0 & 4.81 & 0.44 \\
\hline Q5 & $\begin{array}{l}\text { The case study allowed me to retain more from the } \\
\text { class. }\end{array}$ & 73.1 & 23.1 & 3.8 & 0.0 & 0.0 & 4.69 & 0.54 \\
\hline Q10 & $\begin{array}{l}\text { The case study brought together material I had learned } \\
\text { in several other courses }\end{array}$ & 52.1 & 35.4 & 10.4 & 0.0 & 2.1 & 4.35 & 0.84 \\
\hline Q15 & $\begin{array}{l}\text { I took a more active part in the learning process when } \\
\text { we used the case studies in class }\end{array}$ & 78.4 & 15.7 & 3.9 & 0.0 & 2.0 & 4.69 & 0.73 \\
\hline
\end{tabular}


Table 3 Continued

\begin{tabular}{|c|c|c|c|c|c|c|c|c|}
\hline \multicolumn{2}{|r|}{ Question Theme: Thinking, Synthesis and Analysis } & \multirow{2}{*}{$\begin{array}{r}\text { SA } \\
80.8\end{array}$} & \multirow{2}{*}{$\begin{array}{c}\text { A } \\
17.3\end{array}$} & \multirow{2}{*}{$\begin{array}{c}\mathbf{N} \\
1.9\end{array}$} & \multirow{2}{*}{$\begin{array}{c}\text { D } \\
0.0\end{array}$} & \multirow{2}{*}{$\begin{array}{l}\text { SD } \\
0.0\end{array}$} & \multirow{2}{*}{$\begin{array}{c}\text { SD } \\
4.79\end{array}$} & \multirow{2}{*}{$\begin{array}{l}\text { std } \\
0.46\end{array}$} \\
\hline Q2 & $\begin{array}{l}\text { The case studies helped me analyze the basic elements } \\
\text { of the course concepts }\end{array}$ & & & & & & & \\
\hline Q4 & $\begin{array}{l}\text { The case studies were helpful in helping me synthesize } \\
\text { ideas and information presented in the course }\end{array}$ & 75.0 & 23.1 & 1.9 & 0.0 & 0.0 & 4.73 & 0.49 \\
\hline Q7 & $\begin{array}{l}\text { I thought the use of the case studies in the class was } \\
\text { thought provoking. }\end{array}$ & 67.3 & 19.2 & 5.8 & 1.9 & 5.8 & 4.40 & 1.09 \\
\hline Q9 & $\begin{array}{l}\text { The case study allowed me to view an issue from } \\
\text { multiple perspectives }\end{array}$ & 72.3 & 23.4 & 4.3 & 0.0 & 0.0 & 4.68 & 0.56 \\
\hline Q22 & $\begin{array}{l}\text { The case studies allowed for a deeper understanding of } \\
\text { the course material }\end{array}$ & 73.9 & 21.7 & 4.3 & 0.0 & 0.0 & 4.70 & 0.56 \\
\hline \multicolumn{2}{|r|}{ Question Theme: Classroom Environment/Instruction } & SA & A & $\mathbf{N}$ & D & SD & SD & stdv \\
\hline Q6 & $\begin{array}{l}\text { I felt that we covered more content by using the case } \\
\text { study in class }\end{array}$ & 61.5 & 25.0 & 13.5 & 0.0 & 0.0 & 4.48 & 0.73 \\
\hline Q8 & $\begin{array}{l}\text { The use of case studies allowed for more discussion of } \\
\text { course ideas in the class }\end{array}$ & 78.8 & 19.2 & 1.9 & 0.0 & 0.0 & 4.77 & 0.47 \\
\hline Q11 & The case study added a lot of realism to the class & 64.0 & 28.0 & 8.0 & 0.0 & 0.0 & 4.69 & 0.73 \\
\hline Q12 & I was more engaged in class when using the case study & 74.5 & 23.5 & 2.0 & 0.0 & 0.0 & 4.73 & 0.49 \\
\hline Q14 & $\begin{array}{l}\text { I felt immersed in the activity that involved the use of } \\
\text { case studies }\end{array}$ & 62.0 & 24.0 & 14.0 & 0.0 & 0.0 & 4.48 & 0.74 \\
\hline Q18 & $\begin{array}{l}\text { I found the use of case studies format challenging in } \\
\text { the class }\end{array}$ & 27.5 & 7.8 & 11.8 & 21.6 & 31.4 & 2.78 & 1.63 \\
\hline Q19 & Most of the students I know liked the case studies & 78.4 & 15.7 & 3.9 & 0.0 & 2.0 & 4.56 & 0.64 \\
\hline Ques & tion Theme: Negative Impression & SA & A & $\mathbf{N}$ & D & SD & SD & stdv \\
\hline Q13 & $\begin{array}{l}\text { The case studies was more entertaining than it was } \\
\text { educational }\end{array}$ & 31.4 & 13.7 & 33.3 & 17.6 & 3.9 & 3.51 & 1.22 \\
\hline Q16 & $\begin{array}{l}\text { I was frustrated by ambiguity that followed when using } \\
\text { the case study }\end{array}$ & 13.7 & 3.9 & 19.6 & 39.2 & 23.5 & 2.45 & 1.29 \\
\hline Q17 & $\begin{array}{l}\text { I felt that the use of case studies in the course was } \\
\text { inefficient }\end{array}$ & 13.7 & 3.9 & 7.8 & 23.5 & 51.0 & 2.06 & 1.42 \\
\hline Q20 & $\begin{array}{l}\text { I needed more guidance from the instruction about the } \\
\text { use of the case studies in the class }\end{array}$ & 15.7 & 3.9 & 19.6 & 33.3 & 27.5 & 2.47 & 1.36 \\
\hline Q21 & The case studies took more time than it was worth & 9.8 & 3.9 & 11.8 & 31.4 & 43.1 & 2.06 & 1.27 \\
\hline
\end{tabular}




\section{Evaluation of reports by external reviewers}

Student team reports were evaluated in terms of overall report quality, data analysis, use of tables and figures, and evidence of critical thinking in the results and discussion section of the report. Scoring ranged from 0 for poor quality/no evidence to 3 for exemplary. The evaluator scores were averaged and are displayed by category in Table 4. Scores of student teams in the intervention group are moderately higher than those of the control group in each of the four categories. Generally speaking, student teams in the control group produced reports with 2-3 sentence discussions of limited scope, poorly integrated tables and figures, and little to no in depth analysis of the implications of the collected data. Conversely, student teams in the intervention group produced reports with discussions more clearly connected to practical applications, tables and figures appropriately placed for integration in the text, and detailed interpretation and analysis of the data and the implications for practical application. Despite the slight differences in the scores between the intervention versus control groups, only the critical thinking scores began approaching a statistically significant difference between the mean for the control compared to the intervention ( $p=0.051)$. More data and assessment of student reports is needed to confirm if we are seeing an increase in critical thinking by the intervention group. These results suggest that the use of the case study teaching method may demonstrate the potential to raise students' critical thinking abilities to the higher levels of Bloom's Taxonomy.

Table 4. Mean scores of student reports graded by the external evaluators

\begin{tabular}{|c|cc|cc|c|c|}
\hline & & & & & & \\
RESULTS & Control group & Intervention group & $\begin{array}{c}\text { Significantly } \\
\text { two-tail }\end{array}$ & $\begin{array}{c}\text { different } \\
\text { means }\end{array}$ \\
\hline & Mean & stdev & Mean & stdev & & \\
Report Quality & 2.44 & 0.50 & 2.64 & 0.50 & 0.328 & No \\
$\begin{array}{c}\text { Data Analysis } \\
\text { Tables and Figures }\end{array}$ & 2.19 & 0.73 & 2.45 & 0.69 & 0.349 & No \\
$\begin{array}{c}\text { Analysis and Critical } \\
\text { Thinking Results and } \\
\text { Discussion }\end{array}$ & 2.19 & 0.88 & 2.18 & 1.17 & 0.989 & No \\
\hline Mean & 1.81 & 0.73 & 2.45 & 0.82 & 0.051 & Marginal* \\
\hline
\end{tabular}

Note: $(*)$ Approaching a significant difference due to value being close to $p \leq 0.05$. More data is needed to confirm if the data is significantly different or not significantly different

\section{Conclusion}

Overall, the use of case studies appears to provide a teaching method that can engage students in laboratory courses differently. The learning style profiles confirmed that our engineering students were active, sensing, visual, and sequential. The four cases could be designed to match the learning styles represented by our students and allowed us to linked environmental engineering concepts with real world scenarios. The active learners were able learn by doing something active such as discussing the cases and using skills to analyze data 
related to the cases. The cases could be used to address the sensing learning style by providing students with the opportunity to learn facts about the cases from on-line sources and by researching the topics during their assessment of their lab results. Visually, the pictures and videos used with the cases helped aid visual learning. The structure provided by presenting the case along with organized laboratory instructions to analyze the data matched the sequential learning style. The cases developed for the course actively engaged the students in current and relevant stories about E-waste, the 2014 Duke Coal Ash Waterway Spill, Confined Animal Feeding Operations, and green engineering. The students positively responded to the use of cases in a laboratory course and felt the cases diverged from a traditional laboratory format. The students suggested that teachers who decide to use case studies should to be strategic with their use of the cases and diversify the teaching techniques used based on the type of course and the teaching objective. Our goal for the next two years of funding is to continue to evaluate the quality and critical thinking demonstrated in the student laboratory reports. More data is needed to confirm if the cases can reach higher levels of Bloom's Taxonomy. We are interested in publishing our current cases with the National Center for Case Studies Teaching in the Sciences, writing more cases featuring laboratory activities, and working with a community of faculty interested in using cases in their courses.

\section{Acknowledgements}

Special thanks to our funding source, the National Science Foundation IUSE Award Grant $\# 1431446$. Additionally, this work is a continuation of work previous funded by the National Science Foundation TUES program (Award \#1140109). Additional thanks to Dr. Scott Simkins, the Director for the Academy for Teaching and Learning at North Carolina A\&T State University.

\section{References}

1. Luckie, D. B.; Aubry, J. R.; Marengo, B. J.; Rivkin, A. M.; Foos, L. A.; Maleszewski, J. J., Less teaching, more learning: 10-yr study supports increasing student learning through less coverage and more inquiry. Advances in physiology education 2012, 36, (4), 325-335.

2. Felder, R. M.; Brent, R. In The ABC's of Engineering Education: ABET, Bloom's taxonomy, cooperative learning, and so on, Proceedings of the 2004 American Society for Engineering Education Annual Conference \& Exposition, 2004; 2004; p 1.

3. Momsen, J. L.; Long, T. M.; Wyse, S. A.; Ebert-May, D., Just the facts? Introductory undergraduate biology courses focus on low-level cognitive skills. CBE-Life Sciences Education 2010, 9, (4), 435-440.

4. Abraham, M. R., What can be learned from laboratory activities? Revisiting 32 years of research. Journal of Chemical Education 2011, 88, (8), 1020-1025.

5. Pavelich, M. J.; Abraham, M. R., An inquiry format laboratory program for general chemistry. Journal of Chemical Education 1979, 56, (2), 100-103. 
6. Herreid, C. F., Case Studies in Science: A Novel method of Science Education. Journal of College Science Teaching 1994, (February), 221-229.

7. Stineer, A.; McMillan, B. A.; Metz, D.; Jilek, J. M.; Klassen, S., The Renewal of Case Studies in Science Education. Science and Education 2003, 12, 617-643.

8. Yadav, A.; Lundeberg, M.; DeSchryver, M.; Dirkin, K.; Schiller, N. A.; Maier, K.; Herreid, C. F., Teaching Science with Case Studies: A National Survey of Faculty Perceptions of the Benefits and Challenges of Using Cases. Journal of College Science Teaching 2007, 37, (1), 34-38.

9. Domin, D. S., A Review of Laboratory Instruction Styles. Journal of Chemical Education 1999, 76, (4), 543.

10. Hofstein, A.; Lunetta, V. N., The laboratory in science education: Foundations for the twenty-first century. Science Education 2004, 88, (1), 28-54.

11. Yadav, A.; Lundeberg, M.; DeSchryver, M.; Dirkin, K.; Schiller, N. A.; Maier, K.; Herreid, C. F., Teaching science with case studies: A national survey of faculty perceptions of the benefits and challenges of using case studies. Journal of College Science Teaching 2007, 37, (1), 34-38.

12. Herreid, C. F., What Makes a Good Case? Some Basic Rules of Good Storytelling Help Teachers Generate Student Excitement in the Classroom. Journal of College Science Teaching 1997, 27, (3), 163-165.

13. Herreid, C. F., What is a Case? Bringing to Science Education the Established Teaching Tool of Law and Medicine. Journal of College Science Teaching 1997, 27, (2), 92-94.

14. Litzinger, T. A., Lee, S. H., Wise, J. C., \& Felder, R. M., A psychometric study of the index of learning styles. Journal of Engineering Education 2007, 96, (4).

15. Zywno, M. S. In A contribution to validation of score meaning for Felder-Soloman's index of learning styles, Proceedings of the 2003 American Society for Engineering Education annual conference \& exposition, 2003; American Society for Engineering Education Washington, DC: 2003; pp 1-5.

16. Felder, R. M.; Spurlin, J., Applications, reliability and validity of the index of learning styles. International Journal of Engineering Education 2005, 21, (1), 103-112.

17. Luster-Teasley Stephanie; Locklear, J.; King, N. No Longer Fond of the Local Pond: A Case and Laboratory for Elementary Water Analysis. http://sciencecases.lib.buffalo.edu/cs/collection/detail.asp?case id=781\&id=781

18. Luster-Teasley, S.; Ives, R. Farmville Future? http://sciencecases.lib.buffalo.edu/cs/collection/detail.asp?case $\mathrm{id}=687 \& \mathrm{id}=687$

19. Yadav, A.; Shaver, G. M.; Meckl, P., Lessons learned: Implementing the case teaching method in a mechanical engineering course. Journal of Engineering Education 2010, 99, (1), 55-69.

20. Felder, R. M., \& Silverman, L. K. , Learning and teaching styles in engineering education. Engineering education 1988, 78, (7), 674-681. 